talized. centralized and medicalized, to allow a gradual transfer to a more social and community orientated multidisciplinary approach for psychiatric treatment. One possible option would be to designate a proportion of existing psychiatrists interested in a community-orientated approach to act as front-runners for a limited period of time to facilitate the necessary changes towards community care, working in close partnership with area health planners and policy makers much as community medicine specialists do in their field.

I do not think we can possibly achieve the sort of co-ordinated services that will be required to cope with psychiatric problems in the community without a great deal of preparatory ground work and good will from the psychiatric profession. Apart from our specialist function, we probably have a part to play in establishing good working relationships with the many agencies involved and in the setting up of interdisciplinary liaison meetings. However, in the course of such community work, assumptions about the doctor always having authority over other workers may need to be questioned. The whole balance of responsibility, accountability and priorities may well be very different within the community team as opposed to a hospital based team.

I believe such changes cannot be produced by paper directives alone. and that very positive action and energy will have to be extended to effect this new approach to psychiatric management. Hence, it is my belief that we should designate community psychiatric specialists, even if temporarily, to help facilitate and discriminate positively towards the concept of community care. Psychiatrists currently working in the traditional model usually have neither the time, energy nor motivation to leave their busy work roles and establish new footings in the community. If community care is to work, it must not be left to devclop by chance or by fault.

Royal Edinburgh Hospital

Judy GReEnWOOD

Edinburgh

\section{Part-time posts in psychiatry}

Dear Sirs

I was interested to read $R$. Toms' article about part-time training in psychiatry (Bulletin, June 1984, 8, 104-106). I trained part-time, starting in 1974 when both my children were at school, and I share with her many of the difficulties that she experienced: waiting endlessly for job approval and finance. grappling with an unfamiliar exam format and coping with the problems of being tied to a geographical base. I started in the local psychiatric hospital and after four years was seconded to the academic centre $\mathbf{4 0}$ miles away for one year. Once I passed the Membership and gained a senior registrar appointment the Joint Committee on Higher Psychiatric Training requirements were that I should spend all my time at the academic centre, thus adding three hours" travelling time to each working day. I had found a limited year's secondment manageable, but the prospect of four or more years as a senior registrar making this journey filled me with dismay. However, I persisted and, in order to hurry along the time that I might consider myself qualified enough to apply for a consultant post, did some locum part-time consultant work in my own area.

After about a year of this routine my husband's job moved south, and we decided it was easier for me to apply for a consultant post than renegotiate with a new Regional Health Authority about continuing part-time senior registrar training. We had also decided that I would not move house again so could undertake the long-term commitment which I felt was necessary to a consultant post. Fortunately for all of us, jobs became available in areas convenient to the family, and I applied and was appointed to my present post. At each interview (I attended two) my training was fully discussed by the College representa. tive on the interviewing board. The rest of the interview probably followed much the same format as for other candidates, except that my commitment to psychiatry was questioned.

I felt that the rigours of part-time training were such that only the very committed would survive them! I think it is for this reason that I write, to warn other candidates who move from part-time to full-time jobs that this may be what they face. Perhaps, if I had continued to work in my own area where I was known, there would have been no question about my commitment and it may only be that I moved into a new Health Authority that this occurred. However, it is quite common for consultants to divide their time between establishmentsprivate or NHS practice; clinical and academic work-they are effectively working part-time in various areas and I find it difficult to understand why women who choose to divide their time between work and home cannot be regarded in the same way. In a society that is moving towards a shorter working week there may be much that the medical profession can learn from parttimers.

On reflection, two aspects of my part-time training stand out. Firstly, the difficulties associated with being tied to a geographical base. the limitation of opportunities. amount of time spent travelling and the sense of isolation: and secondly, the enormous amount of support and encouragement I received throughout from a small group of local and regional administrators and colleagues from senior house officer to professor, but particularly other part-timers.

\section{Seymour Clinic}

D. M. Fountain

Swindon

\section{Must psychoanalysis be scientific?}

\section{Dear Sirs}

Dr King's thoughtful article, 'Must Psychoanalysis be Scientific?' (Bulletin, August 1984, 8, 152-54), arrived at the rather tentative conclusion that psychoanalysis, and similar attempts to understand the mind, should not be rejected because they are unscientific. Nobody is likely to dispute this as a proposition standing on its own, but perhaps one should go on to consider the next question: in what way should systems of thought likc 